I Universidade Federal do Rio de Janeiro (UFRJ), Departamento de

Sociologia, Rio de Janeiro, RJ, Brasil

fredericvdbrio@gmail.com

https://orcid.org/o0oo-0003-06I4-8420

Frédéric Vandenberghe'

\title{
FROM JOURNALISM TO CULTURAL SOCIOLOGY (AND BACK VIA PARSONS). AN INTERVIEW WITH JEFFREY ALEXANDER
}

In October 20I4, at UFRJ's Colégio Brasileiro de Altos Estudos, I conducted an interview with Jeffrey Alexander, professor of Yale University and an indispensable reference point for contemporary sociological theory and the field of cultural sociology. In this interview, Alexander provides an overview of his academic trajectory, spanning from his formative period to his plans for future work over the next few years. Interestingly, he talks openly about his relation to Talcott Parsons's legacy and indicates what he considers his main contribution to cultural sociology and a sociology of the civil sphere. This interview opens Sociologia \& Antropologia's special issue on his work. It is less a retrospective and more a substantive evaluation of the questions that this work raises, whether à propos the classics of sociology or the theoretical frontiers inaugurated by his own work.

The interview is followed by an unpublished text by the author, discussing the relations between the social sciences and the field of the humanities from his theoretical framework of cultural sociology. The issue also contains articles by Jean-Francois Côté and Raquel Weiss. A professor of sociology at the Université du Québec à Montréal (UQAM), Côté has studied indigenous theater in Canada and thus knows the ins and outs of theater and performance studies. Drawing on authors and traditions that Alexander ignores, from Artaud to Boal, he argues for a stronger historical and a more dialectical interpretation of the theater than Alexander is willing to offer. Weiss, who directs the Brazilian Center for Durkheimian Studies at the Federal University of Rio Grande do Sul (UFRGS) in Porto Alegre, has reread parts of Alexander's work, and probed its 
Durkheimian references. While she fully recognizes the importance of his early reconstruction of Durkheim's oeuvre, she shows that his neo-Durkheimian cultural sociology takes some freedom with the letter of the text of the master, but only to better preserve his spirit. This creative interpretation is necessary, she argues, to renew the stuffy field of Durkheim Studies.

Knowing the importance of teaching and supervision in the formation of the Yale School, we have also solicited shorter pieces on cultural sociology from four of his former PhD students who have since become academics in their own right. Ron Jacobs starts the series with a personal analysis of the development of cultural sociology, while Isaac Reed complete it with a more theoretical reflection on civil power in Weber, Arendt and Alexander. In between, Matthew Norton shows that notwithstanding his influence on American sociology, Alexander has consistently steered clear of its mainstream, whereas Lisa McCormick sees him as an iconic intellectual with strong performative power. ${ }^{\mathrm{I}}$

Before turning directly to the interview, I briefly reconstruct the main thematic force fields that structure Jeffrey Alexander's production.

Jeffrey Alexander has become an elder statesman of sociology, not just in the United States, but worldwide. For four decades now, he has been at the forefront of sociological theory and cultural sociology, setting the research agenda of social theory in the post-positivist mode, opening up new perspectives in the sociology of culture, creating a host of new concepts ('the scientific continuum,' 'culture-structures,' 'sacralization and pollution,' 'fusion,' 'civil repair,' 'societalization,' etc.), leading an influential school and a prestigious research center at Yale University, rethinking the past of sociology, reflecting on the present state of society and democracy, and maintaining reasonable hope for future justice and solidarity (Mast, 20I5). The importance of his contributions by itself justifies this special issue of Sociologia \& Antropologia. It is also an opportunity to present some of his later work on cultural sociology to a Brazilian audience, and to showcase its relevance for the understanding of the political drama the country is facing in the current disjuncture.

In Brazil, there is hardly a student in sociology who has not read his texts in translation on the function of the classics in sociology ("The Centrality of the Classics" [1987a]) or on the synthetic sociologies of the I980s ("The New Theoretical Movement in Sociology" [1987b]). Alexander, however, is not only a prime commentator of the field of social theory. He himself is a firstclass theoretician. The milestones in his intellectual career are clear: from an influential metatheoretical reconstruction of the classics (1970-80s) to the revisionist promotion of neofunctionalism as a post-Parsonian theory of systemic differentiation (I980s to mid-I990s), and, since then, with more success, 
to the development of cultural sociology as a progressive research program. The so-called Strong Program in Cultural Sociology has its own trajectory, and comes with regular installments, inflexions and innovations - from Structural Hermeneutics and Cultural Pragmatics to Political Sociology of the Civil Sphere.

In addition to an acute sense of positioning in the academic field, Alexander's habitus is characterized by a remarkable mastery of the academic literature (the Civil Sphere came with 165 pages of bibliographic footnotes), a rare topological capacity to see constellations and propose synthetic motions, a pleasantly flowing prose with an almost journalistic style (even when he's writing theory), and, last but not least, a consequent moral and political defense of universalism, democracy and progressive social movements. Indeed, from his early engagement on the radical left to his latest work on the sociology of scandals, his work has been animated by a belief in the transformative power of ideas and ideals (Alexander, 2005). His sociology is, therefore, not only theoretical and empirical; at once public and civic, it is also normative, critical and reconstructive.

\section{FOUR THEMATIC FORCE FIELDS}

In Alexander's distinguished academic career, which has led him from Harvard and Berkeley to UCLA and Yale, we can distinguish four thematic force fields that succeed, intersect and reinforce each other: I) Social Theory and Metatheory; 2) Neofunctionalism; 3) Cultural Sociology; and 4) Political Sociology of the Civil Sphere. We call these thematic force fields rather than temporal phases because, as the interview in this special issue amply shows, in spite of appearances (and, possibly, even self-understandings), there is actually a lot of continuity in the work of America's leading social theorist. At the high point of the metatheoretical phase, he wrote two applied empirical studies (one on journalism and another on inclusion) that anticipate much of his cultural sociology of the civil sphere. Similarly, his cultural sociology can also be read from a metatheoretical perspective and, seen in retrospect, his interpretations of Durkheim and Weber can be understood as excavations of the founding fathers of cultural sociology. In any case, Talcott Parsons is never far away and one can always trace the thematic continuity throughout his large oeuvre, from his early articles on formal and substantive voluntarism through his analyses of the Watergate scandal, the role of journalism and the institutions of the civil sphere, right up to his forthcoming book on social crises and the 'societalization' of social problems (Alexander, 20I9).

\section{Social Theory and Metatheory}

The first force field - Social Theory and Metatheory - is properly theoretical, interpretative and reconstructive. It advances towards conceptual synthesis through critical exegesis of the works of others. Since his doctoral thesis, de- 
fended at the University of California at Berkeley in I978 under the guidance of Neil Smelser and Robert Bellah, the young and ambitious theorist has made his name and risen to fame as a powerful interpreter of the great authors of sociology - from Marx, Weber and Durkheim to Parsons, Habermas and Bourdieu (on the latter, see Alexander, I995: I28-2I7). With the Structure of Social Action (Parsons, I937) as a prototype of (and for) a multidimensional social theory that refuses any reduction of action, order or the relationship between both, to the conflations of idealism (Durkheim and Lévi-Strauss), materialism (Marx and Bourdieu), individualism (Weber and Coleman) or collectivism (Durkheim and Althusser), Alexander defends a post-positivist conception of social science, probes the conceptual architectures, reconstructs the theoretical frameworks, and submits the transcendental assumptions of the great sociological theories to a stringent metatheoretical analysis. And he does so with the systematic intent to strengthen social theories through interarticulation of their complementarities.

In Theoretical Logic in Sociology (Alexander, I982-I983, 4 vols.) and Twenty Lectures (Alexander, I987C), which can be considered the fifth volume of his monumental metatheoretical enterprise, he concludes that Marx and Durkheim failed to construct a multidimensional theory of action and order in modern societies; that Weber was correct in theory, but failed in practice; that Parsons succeeded, but only if one subjects him to a rigorous correction that incorporates all the criticisms of his work; that neo-Marxist theories of conflict, poststructuralist theories of power, British Cultural Studies and Bourdieu's sociology of domination all proceed by way of a materialistic reduction that stresses capital, power and strategies to the detriment of culture, symbols and meanings; and that Schütz, Blumer, Goffman and Garfinkel, on the other hand, with their emphasis on the context of action and interaction, have difficulty grasping the collective and structural dimensions of social life.

Through assimilation, recombination and articulation of the functionalist, interactionist and critical theories of society, the exegetical work eventually found its accomplishment in an outline of a multidimensional theory of action with macrosociological intent that overcomes the opposition between agency and structure, power and signification, reproduction and innovation (Alexander, I988). Thanks to this new synthesis - in fact, a new syncretic theory of convergence that points to the interarticulation of Durkheim's cultural anthropology with Weber's interpretive sociology and Marx's political sociology - Alexander enters with Bourdieu, Habermas, Giddens, Collins and Luhmann in the gallery of the great theorists of the eighties who, each in their own way, revisited the classics of sociology, incorporated the theoretical developments of the I970s, and proposed an ambitious system of concepts that parse the relation between action, culture and social systems. 


\section{Neofunctionalism}

The second force field - Neofunctionalism - derives directly from the first. It proposes a revision and revitalization of the project of Talcott Parsons, whose course Alexander took as an undergraduate student at Harvard. The idea is to fully incorporate the variegated critiques that have been directed at the towering figure of post-war world sociology, not just the action-theoretical critiques of systems theory and the conflict-theoretical ones of consensus theory, but also the more ideological critiques against the establishment, so as to construct neofunctionalism as a theoretical position on the Left that is definitely postthough not anti-Parsons.

This attempt to develop a culturally sensitive, action-based and politically relevant theory of functional differentiation in modern democratic societies, and to field it as an alternative to Luhmann, Habermas, Eisenstadt or Münch, failed, however, and was abandoned in the mid-I990s (Alexander, I998). Although his idea to extend the theory of functional differentiation with a semiotic theory of culture was not wrong, the truth is that Alexander went through a mid-life crisis and no longer wanted to be an epigone. He wanted to make his own theory and work on empirical materials. Avoiding the extremes of the scientific continuum (metaphysical speculation and empiricist observation), he transformed his more abstract reflections on action, order and civil society into a medium-range qualitative research program on culture, media and politics.

\section{Cultural Sociology}

Thus, Cultural Sociology emerged as a third force field with paradigmatic ambitions. Although functionalist themes, such as culture, value-generalization, systemic interchange and inclusion will remain present in his later work, the Parsonian language would, henceforth, largely go underground. Like Clifford Geertz and Robert Bellah, who had also subjected Parsons to an immanent critique, shifting the cursor from the normative to the symbolic, narrative and expressive dimensions of culture, Alexander departs from the grand theorist and formulates the Strong Program of Cultural Sociology (Alexander, I996; revised and rewritten with Phil Smith in I998, republished in Alexander \& Smith, 2003a: I I-26; cf. also Alexander \& Smith, 2010 and Alexander, Jacobs \& Smith, 2012 for a state of the art).

The Strong Program is understood both as a theoretical manifesto that forcefully brings the 'cultural turn' from the humanities, anthropology and history into sociology, and as a research program with transposable and adaptable concepts that allow for the implementation of the theoretical mission statement in a series of empirical investigations on codes, genres, narratives, rituals and affects. Later, in an attempt to supplement the cultural turn with further performative, iconic and material turns, political dramas (Alexander, 
2013a and 2017), cultural traumas (Alexander, 2012) and material icons (Alexander, Bartmanski and Giesen, 2012) will appear as conceptual extensions of the original vision, and obligatory add-ons to the expanding repertoire of the Yale School of Cultural Sociology.

Structural Hermeneutics: At first, the program is defined negatively. Against sociologies of culture and cultural studies that explain culture as a superstructure that is always 'overdetermined' by the correlations of force between groups vying for or against hegemony, cultural sociology starts from the reverse assumption and defends the 'analytic independence' and 'relative autonomy' of culture (Alexander, I990: I-27). The phrase 'analytic independence of culture' is not only intended as an idealist alternative and counter project to the determinations of the last instance of cultural Marxism (from Adorno to Zizek); it also contains a wink to Parsons's analytical realism. When culture is analytically independent from social structure, it can be teased out from the rest of society, and analyzed as an ideational realm with causal power and mythopoetic force. Culture is not a 'reflection' of the base; rather, it is the very basis of social life. Culture is not a system or a subsystem, but a dimension that - like the ether - is omnipresent in every situation of action, in every object, in every practice. Without it, nothing would happen. There would be no meanings, no values, and no actions either. There would be nothing common, and there would be nothing to fight for either. As the totality of symbols, values and feelings that open up, disclose and constitute the world as a human world with meaning and purpose, culture structures, informs and guides social actions 'from within,' as Weber would say.

If the principle of 'analytical independence' endows culture with causal power, giving interpretation an explanatory force, the allied principle of 'cultural autonomy' transforms culture into a text that is independent from its authors and can be analyzed structurally as a semiotic system of discourses and, at the same time, hermeneutically as a web of meanings (Ricoeur, I97I). A structural analysis of culture allows one to apply the formal methods of textual and linguistic analysis to culture at large (monuments and documents, art and artifacts, discourses and practices) and to uncover the system of oppositions that structures and organizes the dispersion of the text through codes and narratives. Following Saussure's classic distinction between the paradigmatic (synchronic) and the syntagmatic (diachronic) dimensions of language (langue and parole), one can either look for cultural codes that arrange signs along binary oppositions (as Lévi-Strauss, Barthes and Sahlins did) or one can look for narrative structures that organize the sequences of actors and events into stories with beginnings and endings (as Propp, Greimas and Ricoeur did). While a structural analysis of culture looks for codes (on the paradigmatic axis) and for narratives (on the syntagmatic axis), a more hermeneutic analysis of culture does not so much seek to explain the unconscious structures that 
organize the text, but to interpret the web of meanings that constitute reality as a human one, and allow actors to understand each other, and act together.

To tease out the collective webs of meaning that inform social action, the director of the Yale Center of Cultural Sociology (CCS) recommends the Geertzian method of 'thick description' - a bit of a misnomer and a misunderstanding, as he concedes (Alexander, 20I I: 57). The point indeed is not so much to describe as to interpret the thicket of meanings. To interpret is not to describe, but to actively re-construct how meanings circulate back and forth between cultural texts and social practices, collective meanings and individual actions. Although the reference to cultural anthropology suggests an engagement with fieldwork, the methodology of the CCS is, in fact, largely desk-driven. The materials of analysis come from the media, quality newspapers above all, which may be related to Alexander's early career as a journalist.

Thanks to the conjunction of French structuralism, German hermeneutics and British-American functionalism, America's best, and best-known, social theorist sought to fuse Durkheim's theory of symbolic representations with Weber's interpretative sociology in a single approach to culture and action that elegantly combines the explanation of texts and discourses with the interpretation of meanings, actions and objects in substantive empirical investigations of dramatic political events (elections, scandals, crises, impeachments, revolts and revolutions) that shake society. From the beginning, Alexander was interested in the whole span of culture, with its tripartite division in symbols and myths (Dilthey and Cassirer), values and norms (Durkheim and Parsons), and rituals and performances (Turner and Goffman).

Two early empirical studies stand out in the development of cultural sociology. The first, on the Watergate scandal, an attempt to impeach President Nixon that ended with his resignation in I974, serves as the matrix and exemplar (in Kuhn's sense) of neo-Durkheimian cultural sociology (Alexander, 2003: I55-177). Inspired by The Elementary Forms of Religious Life, the cultural sociologist regards the episode as an exceptional moment of collective effervescence, and as a democratic ritual in which society rediscovers and reaffirms the basic creeds and sacred values that are at its 'center' (Shils). Applying for the first time the binary code of the sacred and the profane to the discourse of civil society (Alexander \& Smith, 2003b: I2 I-I54), which will be become a standard plank of the repertoire of the CCS, he tracks complex semantic shifts of the signifiers and shows how the meanings of both 'Watergate' and 'Nixon' changed as the latter moved from the profane side (ordinary politics) to the sacred side (Watergate as epitome of scandal, Nixon as exemplar of the villain) of the equation, where good and evil confront each other as archetypical forces of purity and danger.

In another seminal empirical study, this time on the representations of the computer (Alexander, 2003: I79-I92), he discovers the importance of dra- 
matic genres, narratives and plots. Technology is eschatology; as an actant, it is always wrapped up in imaginary significations and narratives that poise it between technophilia and technophobia, and also between apocalypse and salvation. Together, the binary code (on the paradigmatic axis) and the narratives (syntagmatic axis) form the baseline of structural hermeneutics. They indicate a new way of reading politics as an unfolding story in which heroes and villains struggle for the definition of events, actors and situations.

Cultural Pragmatics: Structural hermeneutics offered a text-based and media-centered approach to meaning and action. With its search for codes and narratives, it was still very much a top-down macro-sociological approach to symbolic representations. The reconstruction of culture-structures and the interpretation of meanings blended French structuralism with German hermeneutics in an interpretative sociology that analyzed social action from the thirdperson perspective of the observer. Between the collective representations (as reconstructed by the analyst) and the social actions (as implemented by the actors), there still was a rift, however. The actions lacked sufficient anchoring in concrete situations of action. Although structural hermeneutics already framed politics as a drama and a ritual, it did not take the metaphor of the theater seriously enough. As a neo-Durkheimian investigation of the culturestructures of the code and narrative that organize and drive social life, it also lacked a more situational understanding of meanings typical of American pragmatism and symbolic interactionism. The encounter with Performance Studies (Schechner, 2002), the interdiscipline at the intersection of the anthropology of rituals (Turner), dramaturgic sociology (Goffman) and theater studies, has led to a significant inflection of cultural sociology in which cultural scripts provide the hinge between culture-structures and social actions.

Cultural Pragmatics is the name for a new dramaturgical approach in sociology that analyzes social life as a drama (Alexander, 2013a, 2017). Positioned between ritual and strategy, it analyzes the political scene as a stage on which leaders must work the binaries of civil society, act out the scripts of democracy, and stage performances that display their moral character, while casting their opponents as evil, corrupt and undemocratic figures. In "Cultural Pragmatics: Social Performance between Ritual and Strategy" (Alexander, 2006: 29-90), Alexander draws on theater studies and coins various transposable concepts, such as actors, props, scripts, direction and audience, that suggest how social life in general and politics in particular can be analyzed as a drama. Understanding social life as a drama transforms ordinary events into performances, readers into audiences and actors into characters who plot and scheme, heightening the tension until the curtain goes up. Perhaps, a failed performance in which the actor fails to convince the audience that he or she says what s/he means and means what s/he says, and that consequently appears as histrionic and staged, indicates the importance of a successful 'fusion' of the ele- 
ments that make up the drama of social life. In a successful performance, the actors do not even appear as actors or players. The authenticity may be staged; it does not appear so. The audience experiences the show as reality and, depending on the genre (comedy, tragedy, tragicomedy, etc.), it goes through the motions. Being gripped by the narrative, the plot, the scenes, the characters, it eventually experiences catharsis.

The sociology of trauma (Alexander, 20I2), which is itself a substory of the moral sociology of evil and conflict, constitutes an important extension to the sociology of drama. Over and against the common and psychoanalytic views of trauma, which center on the effects of suffering on the memory and identity of individuals, the theory of cultural trauma adopts a radical constructivist and collectivist view. Horrendous historical events, like the Holocaust, the Partition of the Indian subcontinent or the Nanjing massacre in Maoist China, only become traumas that leave indelible marks on the collective consciousness of a group, changing their identities for ever, as result of a successful 'trauma process' that codes and narrates, constructs and performs the trauma as a collective drama. By attributing responsibility, the trauma process significantly changes the meaning of the event, as well as the collective identity of both the victims and the perpetrators. In other words, it is not the pain and the suffering that causes trauma. Rather, it is the trauma that frames the pain, resignifies the suffering and performs the collective identity.

Cultural sociology does not deny the material dimension of social life. But it considers it to be an effect of cultural structures and ritual performances that occasionally galvanize society into effervescence, leading either to communion and consensus ('fusion') or to conflict and polarization ('fission') and, from there, cyclically, back to the routinization of everyday life. Taking on materialism on its own turf, Alexander addresses the question of materiality head on. In his more recent work (Alexander, 2008a and b; Alexander, Bartmanski \& Giesen, 20I2), he presents a cultural phenomenology of material objects that owes more to Durkheim's analysis of totemism than Marx's of fetishism. Following his earlier moves from literature (structural hermeneutics) and the performing arts (cultural pragmatics), he now addresses the visual arts (sculpture and architecture above all), and supplements the cultural and performative turns with an iconic turn. The result of this further turn within the cultural turn is a phenomenology of aesthetic experience that conceives of icons 'as performers' (i.e. as actants), endowed with magical powers, that re-enchant the world of things by infusing them with an aura. When objects are sensed and experienced as icons, the meanings of social life take on a sensual form. The magic of the object can be felt by the senses (seeing, touching, hearing, smelling) in the aesthetic experience that condenses deep layers of symbolic and moral meaning by projecting them onto a material surface, or even, as happens with iconic figures like Che Guevara or Mahatma Gandhi, onto a face. In any 
case, for Alexander, one does not need to be an anthropologist to see that the world is never devoid of meaning, charm or aura. If anything, the task of cultural sociology is to describe and interpret the collective meanings that make people act and thus to causally explain the course of the world. Through interpretation of the material artifacts it contemplates with a sense of wonder, cultural sociology re-injects meaning in the material world and thereby re-enchants it for a moment.

\section{Political Sociology of Civil Society}

While structural hermeneutics and cultural pragmatics indicate a more idealist approach to culture, society and politics, Alexander has always had a keen eye for the correlation of forces and power games that oppose interest groups to each other. From his early investigations of the Watergate scandal to his more recent dramaturgical analyses of the rise and fall of Barak Obama (Alexander \& Jaworsky, 20I4), Donald Trump (20I9) and Steve Bannon (Alexander, 20I8), his cultural sociology has always been political. The fourth thematic force field - Political Sociology of Civil Society - shows that his political sociology, as developed in The Civil Sphere, is also thoroughly cultural. This master's work, a tome of 793 pages that was published in 2006 after I7 years of gestation, applies some of the central concepts of cultural sociology (binary codes, narratives, social dramas, cultural traumas and performances) in a post-Parsonian theory of the civil sphere, institutions and social movements that offers an alternative, and a cultural-performative correction to Jürgen Habermas's famous book on the public sphere (Vandenberghe, 2008).

The civil sphere is not a subsystem (the integrative system of the AGILscheme), but an idealized societal community of free, equal and solidary individuals. As a reservoir of utopian aspirations that promises justice and solidarity for all, it is an ideal world that is continuously invoked in public discourses, and used to justify and critique institutions, practices and persons with respect to their proximity or distance from the values that a liberal-democratic society self-consciously proclaims, but which it most often fails to realize. The civil sphere is more than a discourse, however. Over the course of history, it has been institutionalized in a variety of communicative organizations (public opinion, mass media, polls) and regulatory bodies (political parties, political office, law) that guarantee the rule of law, provide a fair distribution of resources, expand the franchise, strengthen the independence of the media, check corruption and recognize the rights and identities of minorities. They hold society up to its own ideals, and criticize it in its own name and values.

While the civil sphere projects an ideal society, 'real civil societies' are, however, always split by the binary discourse. As a quasi-transcendental marker, it defines and divides the political space in terms of civil versus anticivil, opposing those who supposedly incarnate the democratic and republican virtues 
in person to the ones who stand for the opposite. Real civil societies are therefore not only counterfactually unified by civil religion, they are actually also driven apart by discursive strategies of demonization that exclude those who are seen as 'polluted': the racial, ethnic, linguistic, religious or other minorities who are seen as - and sometimes persecuted for being - uncivilized, irrational, undemocratic or otherwise unfit to govern themselves.

Social movements emerge out of the tension between imaginary and real communities, between ideal and actual civil spheres. By appealing to an idealized community of solidarity that includes all and recognizes everyone, they are able to pressure the system, submit it to an 'immanent critique,' and denounce the exclusions and dominations of oppressed groups. In agonistic democracies, performance is everything. The struggle for hegemony is a struggle for the hearts and minds waged in the public sphere, on the streets and in the media. When successful, social movements, like the civil rights movement or the feminist movement, both of which are analyzed at length in The Civil Sphere, initiate processes of 'civil repair.' Their plight is no longer seen as particularistic, but one that concerns the whole of society. Their struggles for recognition lead to 'value-generalization' and inclusion through assimilation, hyphenation or multicultural incorporation of once polluted groups into the societal community of the nation.

In spite of his idealist tendencies, Alexander is only too aware of the 'dark side' of reality (Alexander, 2013b). The long and winding road of civil repair not only leads upwards, but also backwards. 'Frontlash movements,' by progressive vanguards that are ahead of their time, always provoke and produce 'backlash movements,' cultural, social and political counter-movements that aim to undo and unwind the progress towards the institutionalization of the ideas and ideals of the civil sphere (Alexander, 2019).

Once again, we find ourselves at the crossroads of history. The election of Barak Obama was experienced as a terrible shock by the more conservative parts of the population in heartland America. The election of Trump was a typical backlash of the moral majority against the minority. Similarly, in Brazil, the election of Luis Inácio Lula da Silva and the subsequent victories of PT (the Workers' Party) were never fully accepted by the elite and the middle classes. The backlash came with a vengeance and a force that was unexpected.

In their recent volume on the civil sphere in Latin America, which is part of a larger comparative analysis of the civil spheres in other regions of the world, Alexander and Tognato (2018) argue against the typical culturalist (self-) depreciating interpretations of the democratic achievements in the Southern hemisphere in terms of a 'deficit' or 'lack,' expressions of a 'selective,' 'peripherical' or 'incomplete' modernity (due to colonialism, slavery, patrimonialism, dependency, etc.). "The ambition of this volume," they write in the introduction, "is to demonstrate that Latin American civil spheres are powerful, even as they 
are compromised. Certainly, the democratic utopian ideals of Latin American spheres are far from being realized; yet, they have been institutionalized in significant ways, creating the kinds of tension with anticivil culture and institutions that triggers social reform" (Alexander \& Tognato, 2018: 7).

Of course, the recent election of Jair Messias Bolsonaro as president of Brazil may well change everything. "We ain't seen nothing yet." The question in Brazil, but also in the United States and elsewhere, is whether the civil sphere can survive the current process of worldwide decivilization. Some argue that democratic institutions with their checks and balances are solid and that progressive forces will just have to weather the democratic recession. Others are more pessimistic and wonder where this all will end. The horizon seems blocked for the next decade. We desperately need hope and a grand theory that allows us to make sense of the conjuncture. Jeffrey Alexander offers it and that is not the least of his contributions to social theory and cultural sociology.

From its early years as a cultural cult at UCLA (the 'Culture Club') to the establishment of the prestigious Center for Cultural Sociology at Yale in 200I, the Yale School of Cultural Sociology has grown into a sprawling empire. While social theory has largely receded, cultural sociology has become ever more popular in the United States (Smith, 20I8). For sure, Alexander is not the only player in the field, but he is certainly the most prominent, the most active and the most attractive. Three honorary doctorates confirm his standing as an elder statesman of sociology. With innumerous books and articles, translated in many languages, various book series dedicated to Cultural Sociology, a Handbook of Cultural Sociology (Alexander, Jacobs \& Smith, 20I2) that has all the features of a liber amicorum, and, since 2013, a specialized journal too (The American Journal of Cultural Sociology), the Alexandrian Library is vast indeed. 
Frédéric Vandenberghe. I suggest that we start with your interest in journalism because, if I am not mistaken, before you became a famous sociologist, you worked as a journalist. Can you tell us something about your personal and intellectual formation, how you went from being an activist, going to Harvard, becoming a journalist? I would like to propose a rule of continuity. As the interview goes on, we'll be trying to insist on the continuity of your work. No ruptures in your work. Can you construct such a narrative?

Jeffrey Alexander. In my teenage, high-school years I was deeply interested in traditional, electoral politics, as a basis for making the kinds of social reforms initiated by Martin Luther King and Lyndon Johnson - what we called, then, 'the Poverty Program.' I thought I would be a lawyer, but when I entered Harvard, at the age of I 8 , my inclinations changed. I supposed the earliest work that contributed to my intellectual fabric was journalism. I worked for the newspaper of Harvard, which was not only a famous but an excellent student-run newspaper called the Harvard Crimson, in which many journalists who later went on to influential professional careers trained. During these years, I wrote a bit for actual outside papers, The Miami Herald and the Detroit Free Press, and for some national magazines. Later, in the first decades after I begin my academic career, I published a bit in political journals like The New Republic and op-ed pieces in The Los Angeles Times.

As a young journalist at Harvard, I became an expert at research-based "feature" articles - long pieces that would take weeks of interviews, research, and writing. This was great training for me to become a sociologist.

But as my four years at Harvard unfolded, I combined this journalism interest with more intellectual ones. Perhaps most important was my 'major' in a program called Social Studies, an interdisciplinary social theory program, very hard to get accepted into, led by Barrington Moore and Michael Walzer. But also extremely vital, at least psychologically and personally, was my growing political activism. I became deeply involved in left-wing politics, organizing against the Vietnam War, racism, and poverty. Being a radical student made me into an intellectual, of course, because you read social theory to figure out what's so messed up about the world and why. No better training to be a social theorist than being on the left. Possibly on the right, but that's not the path I took.

F.V. Was it in the sixties?

J.A. It was I965-69. At Harvard.

So I always thought about the relationship between social movements and journalism. In journalism, we have our heroes, like David Halberstam, the reporter who went early to Vietnam to uncover the truth of what was going on there. Before that, Halberstam had gone to the US South, accompanying the 
Civil Rights Movement. So there was a tradition of critical journalism that was a model we tried to follow.

I think this experience as a journalist - my father and son had done significant time in journalism as well - not only trained me as a researcher and writer but taught me something about a vital issue in social theory. As I became a social theorist and a sociologist, I never accepted the idea that news was controlled by money. I was critical of the Frankfurtian idea of the cultural industry because I always felt that there was really a profession of becoming a real journalist. You must have a lot of self-control and the capability of using your skills as journalist to find out inconvenient things. And, in fact, one of the first sociology articles I ever published was a paper that made this point, in 'neo-functionalist' terms, and the centrality and understanding of independent journalism became a major part of my later theorizing about the civil sphere, and I even organized a volume published in 2016 about the crisis in journalism, asserting once again that journalism is a self-regulating profession. I think that my years of writing news and features also helped me understand that beyond fact gathering there was 'interpretation,' and that this is central. While news seems to be built upon discovering facts, as a journalist, you aren't a positivist, just finding out things, just putting facts together. And, of course, as I moved towards developing cultural sociology, this practical understanding of my earlier years began to make intellectual sense. Journalism was a form of hermeneutics, rather than a form of discovery.

F.V. Continuing on the topic of journalism. At the beginning of cultural sociology, there's your analysis of the Watergate Scandal. That was a central piece, and one of your basic ideas, the narrative approach, was already there, wasn't it?

\begin{abstract}
J.A. Yeah, I was fascinated by the Watergate Scandal, and it occurred just at the time as I was moving from a Marxist left position towards a more social-democrat, or we would say, critical left-liberalist. The two years of Watergate was a critical moment for my own learning about the complexity of a pluralistic social order where you could overthrow a president, Richard Nixon, a person who had a tremendous victory in $\mathrm{I} 972$, and critical journalism played a gigantic role in the whole process. I thought about all that Watergate meant theoretically for a long time, but never wrote anything until the mid-I980. By then I was crystallizing more cultural sociology, with the notion of culture, built around binaries, and I was very much influenced by hermeneutics, cultural anthropology, structuralists like Levi-Strauss and also Roland Barthes, and theories of narrative. It was then, in I986, that I finally wrote about the Watergate prosecution. It was the first cultural sociology piece I had ever written. I concentrated on the symbolic codes and narratives of Watergate, putting them into a social and insti-
\end{abstract}


tutional and historical context. I understood that it wasn't a ritual in the traditional sense, because it was open-ended and contingent and conflictual. So I was searching for a conceptual framework, which I gradually came, much later, to understand as a 'social performance.' So this incredible personal and intellectual engagement with the Watergate Crisis, which lasted two years, was an important moment of my development. Let's say it was my 'Dreyfus' scandal, which had been so central to Durkheim's later development.

F.V. Were you aware that the Watergate article could become the first piece of cultural sociology or was cultural sociology a result of your theoretical formation in sociology. Is there rupture or continuity between your first piece of cultural sociology and the later developments in theory?

J.A. The breakthrough into cultural sociology did begin with the Watergate piece (the companion of which was an article, written that same year, the computer as "sacred and profane information machine"). This piece was published in a book I edited that appeared with Cambridge UP in the late 8os: Durkheimian Sociology: Cultural Studies. This book was my effort to demonstrate that what I had labeled 'late Durkheim' could be a useful, productive way to analyze modern societies. Subsequently, I went on to develop the 'strong program' position in cultural sociology more explicitly, and to develop a series of empirical studies.

But to understand the move toward cultural sociology you need to see, of course, that this was not simply motivated by empirical studies and existential political encounters. There was a long intellectual history involved for me.

Between I982 and I984, I published the four-volume book Theoretical Logic in Sociology, the fourth volume of which, on Parsons, became a launch path for a movement I created called neofunctionalism, which crystallized in the next year or two. It was an attempt to create a left functionalism, a more conflict-oriented, more 'socialist' and reformist version of Parsonianism that would operate with critical intent. But for a whole series of complicated reasons which I went into in the Introduction and Conclusion to Neofunctionalism and After (I998), I felt the content bleed out of neofunctionalism in the early nineties and I ended my own involvement in the mid-nineties.

Part of this movement away from neofunctionalism was triggered by growing a quite orthogonal interest in developing a distinctive approach to cultural sociology. And I also was developing a theory of what I called the civil sphere (as compared with 'civil society').

But while neofunctionalism developed out of the last volume of Theoretical Logic, there were other things going on in the first three volumes, especially issues surrounding what I called the relative autonomy of meaning, of culture. My argument throughout these volumes was that you couldn't have a voluntaristic theory of action - you couldn't respect the idea that people have a self and 
exercise agency, that they can develop a sense of responsibility and a power for criticism - without making culture relatively independent of social structure. Only if people can reach above power, towards principles, narratives, codes, and collective meanings, only if they feel they have some ownership or potential to make use of these meanings by themselves, can they be independent of social structures. In the course of making this theoretical argument, I reinterpreted Durkheim and Weber. Mainly, I argued that sociology misinterpreted who Durkheim was and what he wanted. Because they lost track of him in I900, thinking he became an anthropologist, with The Elementary Forms of Religious Life. What happened is that Durkheim had a revelation in I 900 that religion was central to modern society and from that point onward he was on the edge of a fundamental reconsideration of modernity. At the same time, he felt that he wanted to study the "most primitive societies" to see how religion worked and how culture worked. So, on the first page, he says something like, "I'm not studying aborigines because I'm interested in their religion, but because I'm interested in the religious man of today." The most important chapter of Elementary Forms is Book Two, Chapter 7, in which Durkheim talks about events in contemporary France. It's a very interesting thing: while ostensibly writing about 'primitive' Aboriginals, Durkheim's really writing about a new way to look at the symbolic in a secular society, or at least in a modern society. So his discussion of ritual, symbol, mana, the division of sacred and profane, and the role of solidarity - he implicitly was arguing these are central to modern societies, not only to ancient ones. So in volume 2 of Theoretical Logic, I recovered these dimensions of Durkheim's work, suggesting that, in fact, the later Durkheimian agenda had never been realized. Then, in Volume 3 of that work, I developed a critique of Weber, that there was a giant discontinuity between Weber's writing on religion and the rest of his work, most significantly his political sociology of modernity. The upshot of my interpretations in these two volumes was that one could use Durkheim to solve the problems of Weber. Basically, I feel that's what I have tried to do for the rest of my intellectual life.

In the beginning, I thought Parsons would be the horse to ride to do that. That I could work with his conceptual skin and shift it in a critical way and make it work. Yet, at the same time, I was developing, with the other side of my brain, a very different kind of sociology. So just a few short years after finishing Theoretical Logic, in I985-6, I wrote the first two articles of this other thing, which was not neofunctionalism but cultural sociology. I discussed earlier the article on Watergate. The other was a very radical piece on the computer as a cultural object, which was very Durkheimian and used the categories of Weber's religious writings. It's called "The Sacred and Profane Information Machine: Discourse About the Computer as Ideology." Looking back on that part of my intellectual life, I was quite conflicted about what I 
wanted to do. The great thing about Parsonian theory was that it provided a highly complex and sophisticated macrosociology, one that had historical grounding. By contrast, the cultural sociology that I was working on at the time was much narrower, almost phenomenological. It was NOT a macrosociology but a method and theory about collective meaning, and there wasn't a whole lot of social theory attached to it. It was 'late-Durkheimian' (plus all the other $20^{\text {th }}$ century inputs I mentioned earlier), and, to be frank, this later Durkheim especially had no conception of power, had little historic ground, had only a very weak sense of institutions - compared to Weber and Parsons (who had built on Weber in this sense). So I think this may explain why I was reluctant to give up on the Parsonian tradition.

I could only solve this problem as I began to develop my theory of the civil sphere, in the course of which I could develop an institutional theory that complemented my cultural sociology.

F.V. Before we get to your work on the civil sphere, I want to go back for a second to certain points about neofunctionalism. We started the interview with journalism, which was very important from the very beginning of your professional life. Is there something in neofunctionalism and in Parsons's theory of the media which might allow for continuity between social theory, neofunctionalism and cultural sociology? Or, in other words, is there something in Parsons, perhaps his theory of symbolic media, that would allow us to construct a continuity with the later phases in your life?

J.A. There was a great deal in Parsons that helped me to develop cultural sociology, but in a general way, not in the 'take-off,' spectacular 'aha!' way that the later Durkheim excited me. Parsons sought to integrate the normative moment with everything, so he was resolutely anti-materialist, even in his extensive discussions of economics and politics. Of particular interest, for the media theory, was his idea of 'influence' as a symbolic medium of exchange, one rooted in what he called the I (integrative) subsystem. This was where his idea of the 'societal community' came from.

F.V. When we look at The Civil Sphere, another way to construct the continuity would be via the societal community. Would you say something more about that? Is The Civil Sphere at the same time an example of cultural sociology and a heritage of neofunctionalism?

J.A. I wasn't conscious of the continuity between these elements of Parsons's work and my own, but they were obviously there. My concern was to find a way to develop a social theory of solidarity which is both cultural and institutional. My feeling at the time was that Parsons had actually completely fucked up, that 
he had ruined the possibility for developing such a theory. Which was why I felt I had to reach back to Durkheim. It's hard to be constructive when you look at the history of your own theory, but certainly after it is done, I do, of course, see the continuity between my ideas about the civil sphere and Parsons's societal community. My incorporation and critiques of Parsons, my incorporation and critiques of Durkheim, and ditto for my relation to Weber, as I tried to correct but also build on his ideas about political power, the nation, law, and citizenship. It was around the time I was finishing The Civil Sphere, in the early or mid-200os, I was asked for one last piece on Parsons, and I let out all the frustrations I had with his approach to solidarity and integration, which he formalized in his various evolutionary writings about the societal community, as well as in various stuff about the U.S. I argued for a profound distance between Parsons's concern with integration/solidarity and a concern with justice. In my civil sphere theorizing, these are intertwined in what I regard as a successful way, but Parsons chose the first over the second. In that article, I let out all the anger that I had been harboring about Parsons's failure to be critical about the worst social developments of modernity, how he ignored the dark side at every possible turn. In my civil sphere theory, contrary to understanding solidarity as an integrative sphere, the civil sphere is often described as being in intense conflict with other spheres in a society. I also convict the civil sphere of an endemic exclusiveness, demonstrating that inclusion has always been connected to the rejection of others, so there is a simultaneous inclusion/exclusion. Parsons insisted that societal community was about inclusion. He was, in a systemic way, blind to the persistent exclusion of an element of modernity. The fact that some forms of domination are consistent with democracy was not something that he registered. So my civil sphere is very related to his thought but is, in a way, so different at the same time.

F.V. Would you describe The Civil Sphere as conflict sociology? Did you try to get away from Parsons, retaining the concern with solidarity, but focusing on social movements, refurbishing normative functionalism as a conflict theory, while at the same time dislocating your attention from the normative sphere to the aesthetic sphere? Can you tell me something about the aesthetic sensibility, which of course does not exclude the emphasis on solidarity, and the importance of aesthetics for cultural sociology? I'm thinking about your work on performance, your writing on the iconic turn. Is that also part of a shift from conflict to consensus and from ethics to aesthetics?

J.A. So Civil Sphere, I wouldn't call it conflict theory, but I'd say it's an attempt to explain conflict from a NON-conflict theory perspective. For Parsons, culture and solidarity would make conflict unnecessary. These were moral ideas that would create a cooperative relationship between people. But for me that wasn't 
sociologically accurate. How could we theorize a strong cultural presence, the power of solidarity, yet not, in any way, escape into the idea of consensus and holistic understandings of society? So the problem of the civil sphere was a problem of justice.

All these are matters that concern, in addition to empirics, moral philosophy and they do not equate with aesthetics and performance per se. The problematique of cultural sociology is different from that of the civil sphere. The first question for the strong program in cultural sociology was: how can we develop a sociological way to incorporate the textual turn towards linguistics that informed semiotics, structuralism, and post-structuralism? Which was very challenging because such incorporation had to meet the criteria of sociology which were empirical, physical, operational, etc. etc. etc. I'm not a structuralist, but there are structuralist influences in my cultural sociology. The challenge is how to use structuralism et al but continue to conceptualize agency? Finally, at the end of the I99os, I ran into performance theory, performance studies. I realized that there was this whole field of performance studies that was of great potential theoretically, and in effect 'solved' the problem of ritual and modernity. By the early 2000 , I was writing my new 'social performance'/'cultural pragmatics' theory, and jointly leading, with Bernhard Giesen, a seminar on the topic. I'm still developing this. I believe it is through cultural pragmatics that cultural sociology can deal with contingency, agency, and multi-dimensionality.

But there was one other giant problem that my cultural sociology had to face, which concerned materiality. I had become convinced that my new theory of performance allowed me to work with the problem of action and power in a different way. But the only way to deal with materiality was via the philosophy of aesthetics. I could only understand materiality without materialism via theories of aesthetic sensibility and form. So, I needed to sociologically conceptualize the five senses and the aesthetic shaping of material forms. All material things are shaped aesthetically, whether consciously or unconsciously shaped. And we encounter objects through our senses, but the aesthetic forms are surfaces which are conventionalized and therefore have sociological and social shape. Beneath this surface is a social discourse that informs our aesthetic experience simultaneously. Despite Geertz's brilliant essay on the Balinese cock fight, his performance work, and his general insistence on aesthetic sensibility, did not deal with aesthetic theory. But he didn't have a theory of tactile physical sensations.

So I see my theorizing about performance and 'iconic consciousness' as core issues in cultural sociology, whereas my civil sphere theory, which includes these issues, is much more a macro theory of justice, inclusion, power, control and participation. In one sense, they are separate; in another, The Civil Sphere is 'applied' cultural sociology. 
F.V. Just one more question and then we can wrap it up. Do you still have another major project? What's the next thing? What are you dreaming about?

J.A. Of course, I am continuing to develop research and publications about cultural trauma, social performance, and civil spheres. In June 2017, I published The Drama of Social Life with Polity, and in August 20 I7 I submitted The Civil Sphere in Latin America to Cambridge University Press, a project that will shortly be followed with The Civil Sphere in East Asia, The Civil Sphere and Radicalism, and The Nordic Civil Sphere. But, in answer to your question, yes, I do have dreams of completing other major projects, despite having just celebrated my $70^{\text {th }}$ birthday. The first is to write the book-length treatment of iconic consciousness. The next is to conceptualize what a global civil sphere would look like, why it hasn't been achieved, and what the consequences of that failure are. The third is to write up my lectures on the development of my own version of cultural sociology. Who knows after that?!!!

F.V. To conclude we would like to ask about academic supervision. For this issue of Sociologia \& Antropologia, we invited four of your former students to contribute a text reflecting on your work. Now we would like to know how you envisage the personal and intellectual dimensions of this supervisor-supervisee relationship, which was so important to the diffusion of the theoretical program of cultural sociology.

J.A. In the US, doctoral students do not arrive in the prêt-à-porter packaging they do most everywhere else. Outside the US, prospective students usually apply to an individual professor, sending them a pretty developed dissertation proposal and inquiring whether they are taking on new doctoral students. In the US, by contrast, students apply to a department, not an individual, for admission to the doctoral program. It is likely, of course, that they so apply because there are professors in that department with whom they wish to work, and it is often the case, indeed, that they have privately contacted these professors in advance of their application. Yet, while individual professors may push for the departmental admissions committee to admit a particular student, success is far from guaranteed. For one thing, their colleagues may not want to enhance their colleague's specialty or perspective, inside the department or, eventually, in the academic world at large. For another, there are always many fewer available slots than there are qualified applicants.

The implications of this oddity of American graduate education deepen when we note that the students eventually admitted to a doctoral program receive guaranteed financial support upon their admission. Once admitted, students are entirely free to study with whomever they wish, to the point of choosing different supervisors for the Masters and PhD. 
These are the 'objective conditions' within which I have worked as a doctoral supervisor during my 25 years at UCLA and my almost 20 years at Yale. As the first and second year doctoral students take a variety of seminars, at least half of which are required, they often have not yet decided with whom they wish to work. Toward the end of their first year, they must make choices, at least for the Masters, or 'second year' paper, after which they will choose a supervisor for their PhD.

If a student decides to work with me, we begin with a long, one-to-one conversation. As I see it, we are beginning to build an intellectual and personal relationship, and I feel strongly that it should be one in which the student experiences herself as a creative, self-generating individual. Our first conversation is intensely focused but also wide-ranging; we chat about broad directions and not so much about specific topics. My goal is to help the student figure out his own topic, not to tell him what a good topic would be. Ideally, their project will emerge from their own deep-seated intellectual ambitions, their unique and particular abilities, and their personal identities as well. I see myself as a facilitator and an interested party, not a boss.

Young people enter sociology with deep normative and political interests. I want to help them translate these into scientific-cum-intellectual projects. It's vitally important for doctoral students, in the midst of the long hard slog of dissertation writing, to continue to feel energized, to experience intellectual vitality, to be able to connect what they are doing to the personal, political, and moral interests that motivated them to pursue doctoral work. This can happen only if the students themselves crystallize their topic. Indeed, the ability to crystallize a proposal is the first and perhaps the most important step of doctoral training. It emerges when 'it's time,' out of a developmental process of maturation and readiness, personally and intellectually.

Of course, I hope that some of my own articles and books, and my broader paradigmatic interests, may provide an impetus to this crystallization. I hope just as intently that the proposal will stake out new ground. The real thrill of supervision is when a PhD student shows me something I have never known, perhaps not even conceived - and this often happens. I want to facilitate adventurous thinking, work that goes against the conventional wisdom of a specialized field, creating a new way of thinking via the application of a broadly cultural-sociological outlook. I encourage students to think in terms of big, paradigm-creating contributions, not just to place articles in journals - important as they are for the US job market - but to do something original, deep, and important. My working assumption has been that every doctoral student has this potential, and that good enough mentoring will allow this potential to become real. One must supervise without a heavy hand, establish quality control and offer assistance without usurping autonomy and constricting intellectual and personal growth. 
In the early stages of thesis preparation, I meet fairly frequently with the doctoral student. What begins as a broad and open-ended conversation eventually becomes specific and concrete. As this process develops, I feel comfortable making strong recommendations of my own, about what exactly should be studied and how, but only insofar as the student's personal enthusiasm, intellectual curiosity, and confidence in their own creativity remain intact.

I am not an intrusive supervisor. I believe that, properly oriented and supported, intellectual achievement unfolds 'naturally,' through the pragmatic and idealistic struggle to solve empirical and theoretical problems. I read the early chapters of dissertations very closely and offer detailed feedback. Later chapters do not receive this kind of attention, but I respond to the finished product with an eye toward future publication, and I encourage students to drop by and discuss problems and breakthroughs along the way.

Supervising a doctoral student is like being inside a Bildungsroman. As the young hero grows, s/he experiences heartache and growth, hopefully not in equal proportion. We develop a powerful intellectual and personal relationship, one that continues long after the dissertation is complete.

Received on 26/I 2/2018 | Approved on I0/2/2019

Frédéric Vandenberghe is a professor and researcher at Universidade Federal do Rio de Janeiro's Instituto de Filosofia e Ciências Sociais. He is the director of Sociofilo and his works focus on social theory, sociological theory and philosophy of social sciences. His publications include Teoria social realista (2010), Pós-humanismo ou a lógica cultural do neocapitalismo global (2017) and As sociologias de Georg Simmel (2018). 


\section{NOTE}

I Together with André Botelho and Antonio Brasil Jr., the editors of the journal, I wish to thank all the participants for their cheerful contributions and Jeff for his generosity, enthusiasm and support. We hope that the publication of a book later this year in Portuguese with a selection of his texts that span his career may be a perfect opportunity to welcome him again to Brazil's shores.

\section{BIBLIOGRAPHY}

Alexander, Jeffrey C. (20I9a). What makes a social crisis? The societalization of social problems. Cambridge: Polity Press.

Alexander, Jeffrey C. (20Igb). Frontlash and backlash: the crisis of solidarity and the threat to civil institutions. International Sociology, I (forthcoming).

Alexander, Jeffrey C. (20I8). Vociferando contra o iluminismo: a ideologia de Steve Bannon. Sociologia \& Antropologia, 8/3, p. 1009-1023.

Alexander, Jeffrey C. (2017). The drama of social life. Cambridge: Polity.

Alexander, Jeffrey C. (2013a): Performance and power. Cambridge: Polity Press.

Alexander, Jeffrey C. (2013b). The dark side of modernity. Cambridge: Polity.

Alexander, Jeffrey C. (20I2). Trauma. A social theory. Cambridge: Polity.

Alexander, Jeffrey C. (20II). Clifford Geertz and the strong program: the human sciences and cultural sociology. In: Alexander, Jeffrey, Smith, Philip \& Norton, Matthew (eds.). Interpreting Clifford Geertz. Cultural investigation in the social sciences. New York: Palgrave, p. 55-63.

Alexander, Jeffrey C. (2008a). Iconic experience in art and life: surface/depth beginning with Giacometti's Standing Woman. Theory, Culture and Society, 25/5, p. I-I9.

Alexander, Jeffrey C. (2008b). Iconic consciousness: the material feeling of meaning. Environment and Planning D: Society and Space, 26/5, p. 782-794. 
Alexander, Jeffrey C. (2006). Cultural pragmatics: social performance between ritual and strategy. In: Alexander, Jeffrey C., Giesen, Bernhard \& Mast, Jason (eds.): Social Performance. Symbolic Action, Cultural Pragmatics, and Ritual. Oxford: Oxford University Press, p. 29-90.

Alexander, Jeffrey C. (2005): The sixties and me: from cultural revolution to cultural theory. In: Sica, Alan \& Turner, Steven (eds.): The disobedient generation. Chicago: University of Chicago Press, p. 37-47.

Alexander, Jeffrey C. (2003). The meanings of social life. A cultural sociology. Oxford: Oxford University Press.

Alexander, Jeffrey C. (I996). Cultural sociology or sociology of culture? Culture, I0/3-4, p. I-5.

Alexander, Jeffrey C. (1995). Fin de siècle social theory. Relativism, reduction and the problem of reason. London: Verso.

Alexander, Jeffrey C. (I990). Introduction: understanding the relative autonomy of culture. in Alexander, Jeffrey C. \& Seidman, Steven (eds.). Culture and society. contemporary debates. Cambridge: Cambridge University Press, p. I5-39. Alexander, Jeffrey C. (I988). Action and its environments. Toward a new synthesis. New York: Columbia University Press.

Alexander, Jeffrey C. (I987a). The centrality of the classics. In: Giddens, Anthony \& Turner, Jonathan (eds.). Social theory today. Cambridge: Polity Press, p. II-57.

Alexander, Jeffrey C. (I987b). The new theoretical movement in sociology. In: Smelser, Neil (ed.). Handbook of Sociology. Newbury Park: Sage, p. 77-IOI.

Alexander, Jeffrey C. (I987c). Twenty lectures. Sociological theory since World War II. New York: Columbia University Press.

Alexander, Jeffrey C. (I982-I983): Theoretical logic in sociology. Berkeley: University of California Press (4 vols).

Alexander, Jeffrey C. \& Smith, Philip. (2003a). The strong program in cultural sociology: elements of a structural hermeneutics. In: Alexander, Jeffrey. The Meanings of social life. Oxford: Oxford University Press, p. II-26.

Alexander, Jeffrey C. \& Smith Philip. (2003b). The discourse of American civil society. In: Alexander, Jeffrey. The 
meanings of social life. Oxford: Oxford University Press, p. I 2 I-I54.

Alexander, Jeffrey C. \& Tognato, Carlo (eds.). (2018). The civil sphere in Latin America. Cambridge/New York: Cambridge University Press.

Alexander, Jeffrey C. \& Jaworsky, Bernadette N. (20I4). Obama Power. Cambridge: Polity.

Alexander, Jeffrey C. \& Smith Philip. (20I0). The strong program: origins, achievements, and prospects. In: Hall, John; Grindstaff, Laura \& Lo, Ming-Cheng (eds.). Routledge handbook of cultural sociology. London: Routledge, p. I3-24.

Alexander, Jeffrey C., Bartmanski, Dominik \& Giesen, Bernhard (eds.). (2012). Iconic power. Materiality and meaning in social life. New York: Palgrave.

Alexander, Jeffrey C., Jacobs, Ronald \& Smith, Philip (eds.). (2012). The Oxford handbook of cultural sociology. Oxford: Oxford University Press.

Mast, Jason. (2015). Alexander, Jeffrey C. (I947-). In: Wright, D. (ed.). International encyclopedia of social and behavioral sciences. Vol. I. Second Edition. Amsterdam: Elsevier, p. 523-528.

Mast, Jason \& Alexander, Jeffrey C. (eds.). (20I9). Politics of meaning/meaning of politics. Cultural sociology of the 2016 U.S. election. New York: Palgrave.

Parsons, Talcott. (I937). The structure of social action. New York: McGrawHill.

Ricoeur, Paul. (I97I). The model of the text. Meaningful action considered as a text. Social Research, 38, p. 529-562. Schechner, Richard. (2002). Performance studies. An introduction. New York: Routledge.

Vandenberghe, Frédéric. (2008). The cultural transformation of the public sphere: sociological inquiry into a category of American society. Constellations, I5/3, p. 422-434. 


\section{DO JORNALISMO À SOCIOLOGIA CULTURAL (E DE VOLTA VIA PARSONS). UMA ENTREVISTA COM JEFFREY ALEXANDER}

Resumo

Além de uma introdução geral à sociologia de Jeffrey Alexander, em que comento alguns dos principais eixos de sua produção sociológica ao longo do tempo (teoria social e metateoria, neofuncionalismo, sociologia cultural e sociologia política da sociedade civil), apresento aqui uma entrevista inédita feita com o autor em outubro de 2014 no Rio de Janeiro. Nessa ocasião, conversamos sobre certos aspectos de sua trajetória pessoal e intelectual, destacando especialmente continuidades e descontinuidades de seu percurso teórico, desde as revisões dos clássicos da sociologia até suas formulações mais recentes sobre a esfera civil, passando pelo lugar do legado parsoniano em sua obra.

\section{FROM JOURNALISM TO CULTURAL SOCIOLOGY ( AND BACK VIA PARSONS). AN INTERVIEW WITH JEFFREY ALEXANDER}

Abstract

Along with a general introduction to Jeffrey Alexander's sociology, in which I comment on some of the main lines taken by his sociological output over the years (social theory and metatheory, neofunctionalism, cultural sociology and the political sociology of civil society), I present here an unpublished interview with the author, conducted in October 2014 in Rio de Janeiro. During this interview, we talked about various aspects of his personal and intellectual trajectory, highlighting especially continuities and discontinuities over his theoretical journey, from the revisions of the classics of sociology to his more recent formulations on the civil sphere, passing through the place of the Parsonian legacy in his work.

\section{Palavras-chave}

Jeffrey Alexander; sociologia cultural; teoria social; teoria sociológica; esfera civil

\section{Keywords}

Jeffrey Alexander; cultural sociology; social theory; sociological theory; civil sphere. 